\title{
IMPLEMENTASI KEWAJIBAN PELAPORAN TENAGA KERJA BAGI PELAKU USAHA TOKO SWALAYAN DI KOTA PEKANBARU
}

\author{
Ardiansah $^{1}$, Silm Oktapani ${ }^{2}$ \\ 1,2Program Studi Ilmu Hukum, Universitas Lancang Kuning \\ Jl. Yos Sudarso Km 8 Rumbai, Pekanbaru \\ e-mail: ardiansah@unilak.ac.id
}

\begin{abstract}
The existence of supermarkets that have penetrated into settlements is an attraction for the people of Pekanbaru City. However, the number of supermarkets is apparently not directly proportional to the attitude of businesses in fulfilling the obligation to report the number of workers. This study aims to identify barriers and explain the solution to the implementation of the obligations of business operators to report the number of workers in each semester ordered by the Pekanbaru City Regulation on Management of People's Markets, Shopping Centers and Supermarkets. This type of empirical legal research is used in this study, wherein a study that looks at law in society. By using data collection methods by observation, questionnaire, interview and literature review. From the results of the research conducted it can be concluded that business actors do not report the number of workers due to their ignorance of the Pekanbaru City Regional Regulation on Management of People's Markets, Shopping Centers and Supermarkets. Efforts that need to be done are related institutions need to synchronize perceptions and disseminate local regulations to business actors in order to carry out their labor reporting obligations and send letters to business actors regarding the deadline for submitting reports on the number of workers in each semester.
\end{abstract}

Keywords; Business Actors, Reporting, Manpower

\begin{abstract}
Abstrak
Keberadaan toko swalayan yang telah merambah hingga ke pemukiman menjadi daya tarik bagi masyarakat Kota Pekanbaru. Namun, banyaknya toko swalayan ini ternyata belum berbanding lurus dengan sikap pelaku usaha dalam menunaikan kewajiban untuk melakukan pelaporan jumlah tenaga kerjanya. Penelitian ini bertujuan untuk mengidentifikasi hambatan dan menjelaskan solusi belum terlaksananya kewajiban pelaku usaha untuk melakukan pelaporan jumlah tenaga kerja pada setiap semesternya yang diperintahkan Peraturan Daerah Kota Pekanbaru tentang Pengelolaan Pasar Rakyat, Pusat Perbelanjaan dan Toko Swalayan. Jenis penelitian hukum empiris yang digunakan dalam penelitian ini, dimana sebuah penelitian yang melihat hukum didalam masyarakat. Dengan menggunakan cara pengumpulan data secara observasi, kuisioner, wawancara serta kajian pustaka. Dari hasil penelitian yang dilakukan dapat disimpulkan bahwa pelaku usaha tidak melakukan pelaporan jumlah tenaga kerja disebabkan ketidaktahuannya terhadap Peraturan Daerah Kota Pekanbaru tentang Pengelolaan Pasar Rakyat, Pusat Perbelanjaan dan Toko Swalayan. Upaya yang perlu dilakukan ialah instansi terkait
\end{abstract}


perlu menyamakan persepsi dan mensosialisasikan peraturan daerah kepada pelaku usaha agar melaksanakan kewajiban pelaporan tenaga kerjanya dan mengirim surat kepada pelaku usaha mengenai batas waktu pengajuan laporan jumlah tenaga kerja pada setiap semester.

Kata Kunci; Pelaku Usaha, Pelaporan, Tenaga Kerja

\section{PENDAHULUAN}

Saat ini, industri yang dinilai strategis dan berkontribusi besar pada perekonomian Indonesia ialah industri toko modern. ${ }^{1}$ Pertambahan penduduk, perkembangan ekonomi, dan peningkatan masyarakat kelas menengah menjadikan perubahan gaya hidup masyarakat dalam hal berbelanja. ${ }^{2}$ Impilkasinya dari tahun ke tahun menunjukkan perdagangan eceran dan distribusi produk mengalami peningkatan yang cukup besar. ${ }^{3}$ Perusahaan harus bisa bersaing untuk menunjukkan keunggulan dari produk atau jasa yang diberikan dibandingkan dari kompetitornya. ${ }^{4}$

Banyaknya tersebar toko swalayan di berbagai daerah di Indonesia menjadi kekuatan tersendiri dan memberikan berbagai keunggulan yang menjadi daya tarik bagi masyarakat. 5 Pelaku usaha semakin menunjukkan inovasinya untuk menempatkan toko swalayannya lebih diminati para konsumen dalam melakukan kegiatan berbelanja. Pelaku usaha menyediakan tempat perbelanjaan yang menyerupai toko menjual segala jenis kebutuhan alat rumah tangga, minuman, dan makanan yang dibutuhkan masyarakat secara lengkap merupakan bentuk dari swalayan.

\footnotetext{
${ }^{1}$ Jun Ramadhani, "Kebijakan Pemberian Izin Usaha Toko Modern Alfamart Dan Indomaret Oleh Pemerintah Kota Pekanbaru Berdasarkan Peraturan Presiden Nomor 112 Tahun 2007 Tentang Penataan Dan Pembinaan Pasar Tradisional Pusat Perbelanjaan Dan Toko Modern", Jurnal JOM Fakultas Hukum, Vol. 2, No. 1 (2015), hlm. 3.

2 Mia Ayu Sukmawati, "Pengawasan Izin Usaha Toko Modern (IUTM) Oleh Dinas Perdagangan Dan Perindustrian Kota Pekanbaru (Studi Kasus Ritel Alfamart Dan Indomaret)", Jurnal JOM FISIP, Vol. 5, No. 2 (2018), hlm. 2.

3 Trisdiana M. Nur, "Analisis Perubahan Pendapatan Usaha Pedagang Eceran Sebelum Dan Sesudah Berdirinya Indomaret Dan Alfamart Di Kecamatan Tampan Pekanbaru", Jurnal JOM FEKON, Vol. 2, No. 2 (2015), hlm. 1.

${ }^{4}$ Melfa Yola and Duwi Budianto, "Analisis Kepuasan Konsumen Terhadap Kualitas Pelayanan Dan Harga Produk Pada Supermarket Dengan Menggunakan Metode Importance Performance Analysis (IPA)", Jurnal Optimasi Sistem Industri, Vol. 12, No. 1 (2016), hlm. 301.

5 Zainal Abidin, "Pelaksanaan Peraturan Daerah Nomor 09 Tahun 2014 Tentang Pengelolaan Pasar Rakyat, Pusat Perbelanjaan Dan Toko Swalayan (Indomaret Dan Alfamart Kota Pekanbaru)", (2018), hlm. 5. http://repository.uin-suska.ac.id/14788/.

6 Dicky Taufik Riyadi, "Pengawasan Dinas Perindustrian Dan Perdagangan Terhadap Izin Usaha Toko Modern (IUTM) Di Kota Pekanbaru", Jurnal JOM FISIP, Vol. 4, No. 9 (2017), hlm. 2.
} 
Mart (Pasar Modern) merupakan pasar yang didirikan oleh swasta, pemerintah, atau koperasi dalam bentuk shoping center, departemen store, supermarket dan mall. Pelaksanaan pasar modern dilaksanakan secara modern, dengan modal yang relatif besar, dan dikelola oleh pengusaha besar. Faktor yang menjadi perhatian bagi pasar modern adalah kenyamana berbelanja bagi para konsumen. Di pasar modern dalam berbelanja tidak terjadi proses tawar menawar seperti di pasar tradisional disebabkan karena setiap barang yang dijual sudah diberi dengan label harga. ${ }^{7}$

Pasar modern bisa dicontohkan dengan toko serba ada, minimarket, supermarket, hipermarket dan pasar swalayan. Perusahaan ritel dengan bentuk pasar modern tidak hanya terbatas dengan membuka satu tipe atau satu bentuk swalayan saja. Beberapa perusahaan ritel di Indonesia yang beroperasi dalam bentuk swalayan dengan memiliki beberapa bentuk, diantaranya : Minimarket dengan merek Macan Mart dan supermarket Macan Yaohan-Hero terdapat di medan, di Jakarta berdiri dengan bentuk Supermarket Hero. ${ }^{8}$ Sekarang ini berkembang Minimarket Alfa Mart dan Indo Maret.

Pasar modern dengan jenis toko swalayan beroperasi dengan menggunakan sistem pelayanan mandiri dimana konsumen berbelanja tanpa pelayanan atau bantuan dari pegawai toko swalayan. ${ }^{9}$ Dalam perkembangannya, semakin banyak tersebar toko swalayan dan perlu ditingkatkan pelayanannya. ${ }^{10}$ Perusahaan harus memberikan pelayanan yang baik kepada konsumen agar tumbuh kepercayaan konsumen. Semakin banyaknya persaingan disebabkan sangat cepatnya peningkatan teknologi, maka setiap perusahaan memerlukan karyawan yang memiliki kompetensi untuk dapat menampilkan pelayanan yang baik dan bernilai tinggi. ${ }^{11}$

Berkenaan toko swalayan ini, Pekanbaru merupakan kota yang sangat pesat pertumbuhan toko swalayannya. Setiap sudut Kota Pekanbaru akan sangat mudah

\footnotetext{
${ }^{7}$ Muhammad Yasin dan Sri lestari, Ekonomi (Jakarta : Ganeca Exact, 2007), hlm 26.

8 Trivita Octaviana; M. Mahdil Mawahib; Abdullah Taufik, "Analisis Strategi Penjualan Barang Komoditas Di Swalayan Surya Gondang Perspektif Hukum Ekonomi Syari'ah", Jurnal Qawanin, Vol. 3, No. 2 (2019), hlm. 166.

${ }^{9}$ Lina Wana Mahyuni, "Implementasi Peraturan Daerah Nomor 09 Tahun 2014 Tentang Pengelolaan Pasar Rakyat, Pusat Perbelanjaan Dan Toko Swalayan (Pengawasan Pusat Perbelanjaan Dan Toko Swalayan Tidak Berizin) Kelurahan Simpang Baru Kota Pekanbaru.", (UIN Suska, 2018). hlm.3. http://repository.uinsuska.ac.id/14780/.

${ }^{10}$ Lisa Tina Ria, "Analisis Faktor - Faktor Yang Mempengaruhi Prilaku Konsumen Berbelanja Pada Swalayan 999 Pekanbaru", (Uin Suska, 2012), hlm. 12. http://repository.uin-suska.ac.id/1617/.

11 JHamdiyah; Andi Triharyono; Azis Fathoni, "Peningkatan Kinerja Karyawan Melalui Kompetensi Lingkungan Kerja Dan Gaya Kepemimpinan Di Ada Swalayan Banyumanik Semarang", Jurnal of Management, Vol. 02.No. 02 (2016), hlm. 2.
} 
untuk mendapatkan toko swalayan dengan brand Indomaret dan Alfamart. Ironinya, Pemerintah Kota Pekanbaru memandang negatif pelaksanaan penertiban Pedagang Kaki Lima, namun memberikan perlakuan yang istimewa terhadap permohonan izin pembukaan toko modern seperti Indomaret dan Alfamart. ${ }^{12}$ Peningkatan Pendapatan Daerah Kota Pekanbaru menjadi alasan Pemerintah Kota Pekanbaru memberikan izin pembukaan toko modern seperti Indomaret dan Alfamart ini. Sepanjang tahun 2018 terdapat 339 gerai Indomaret dan Alfamart yang telah beroperasi di Kota Pekanbaru. Pengelolaan Indomaret dan Alfamart merupakan salah satu dari beberapa perusahaan yang berhasil dan bisa menguasai pasar serta berkompetisi di tengah-tengah ramainya bermunculan pasar modern di Indonesia, terutama di Kota Pekanbaru. ${ }^{13}$

Pelayanan sebagai faktor yang utama dan wajib diperhatikan bagi perusahaanperusahaan yang bergerak dibidang jasa termasuk jasa penjualan barang dagangan. ${ }^{14}$ Perlu strategi untuk menghadapi pelanggan yang tidak merasa puas dengan jasa atau barang yang telah digunakannya karena bila pelanggan tidak puas maka pelanggan akan mencari penyedia jasa atau barang dari perusahaan lain yang dianggap mampu untuk memenuhi kebutuhannya. ${ }^{15}$ Sumber daya manusia yang dimiliki oleh suatu perusahaan adalah pegawai yang dalam melaksanakan pekerjannya memiliki kinerja yang baik dalam kualitas dan kuantitas. ${ }^{16}$

Tidak mudah bagi pelaku usaha untuk menjalankan usaha toko swalayan di kota Pekanbaru. Ada beberapa aturan yang harus dipenuhi pelaku usaha toko swalayan. Pertama, aturan yang berlaku umum, yaitu pelaku usaha toko swalayan harus mendapatkan izin pembukaan usaha. Setiap pelaku usaha harus memiliki Surat Izin Tempat Usaha (SITU) tidak terkecuali terhadap pemilik ritel dan swalayan yang ada di Kota Pekanbaru. ${ }^{17}$ Kedua, aturan yang berlaku khusus, yaitu pelaku usaha toko

\footnotetext{
12 Jun Ramadhani, Kebijakan Pemberian .....Op. Cit., hlm. 3.

13 Khaidir Saib, "Strategi Kesuksesan Pertumbuhan Pasar Swalayan Studi Kasus: Toko Mini Market Di Kota Pekanbaru', Jurnal Equibrium, Vol. 7, No.2 (2019), hlm. 72.

14 Vini Anggraini Putri and Dewi Fatmasari, "Hubungan Kualitas Pelayanan Dengan Kepuasan Pelanggan Alfamart Di Kelurahan Srondol Wetan Semarang", Jurnal Majalah Ilmiah Inspiratif, Vol. 3, No. 5 (2018), hlm. 1.

15 Rizki Nuri Puspita, "Perbedaan Kepuasan Pelanggan Indomaret Dan Alfamart", Jurnal Of Social And Industrial Psychologi, Vol. 1, No.1 (2012), hlm. 62.

16 Ikeu Kania dan Windy Widiawati, 'Pengaruh Pembagian Kerja Terhadap Kinerja Pegawai Di UPTD Pasar Cisurupan Dinas Perindustrian Dan Perdagangan Kecamatan Cisurupan Kabupaten Garut', Pembangaunan Dan Kebijakan Publik, Vol. 10, No.2 (2019), hlm. 24.

17 Dicky Taufik Riyadi, Pengawasan Dinas .... Loc. Cit.
} 
swalayan harus tunduk pada Peraturan Daerah Kota Pekanbaru Nomor 09 Tahun 2014 tentang Pengelolaan Pasar Rakyat, Pusat Perbelanjaan Dan Toko Swalayan. Dalam peraturan daerah tersebut dinyatakan bahwa pelaku usaha memiliki kewajiban untuk menyerahkan pelaporan mengenai jumlah gerai yang dimiliki, omset penjualan seluruh gerai, jumlah Usaha Mikro Kecil dan Menengah (UMKM) yang bermitra dan pola kemitraannya dan kewajiban pelaku usaha toko swalayan melaporkan jumlah tenaga kerja yang telah diserap dalam perusahaannya. Kewajiban yang harus dilakukan ini merupakan amanah dari Peraturan Daerah Kota Pekanbaru Nomor 09 Tahun 2014 tentang Pengelolaan Pasar Rakyat, Pusat Perbelanjaan Dan Toko Swalayan, yang tertuang dalam Pasal 52 ayat (1) butir d menyatakan setiap pelaku usaha wajib menyampaikan laporan berupa jumlah tenaga kerja yang diserap.

Pada prinsipnya, pelaku usaha berkewajiban melakukan pelaporan tenaga kerjanya secara rutin agar pemerintah dapat mengetahui seberapa besar kesempatan perluasan kerja yang mesti dilaksanakan oleh pemerintah dan bagaimana keadaan pekerja yang ada di setiap perusahaan. Pemerintah membutuhkan informasi tenaga kerja dari setiap perusahaan, sementara pelaku usaha berkewajiban melaporkan data jumlah pekerja kepada pemerintah secara rutin. ${ }^{18}$

Kenyataan menunjukkan sebakin banyak usaha toko swalayan di kota Pekanbaru, namun pelaku usaha toko swalayan belum menjalankan kewajibannya sesuai amanat Peraturan Daerah Kota Pekanbaru Nomor 09 Tahun 2014 tentang Pengelolaan Pasar Rakyat, Pusat Perbelanjaan Dan Toko Swalayan. Mencermati hal ini, Kepala Bidang Penempatan Tenaga Kerja Disnaker Kota Pekanbaru, Abdul Rahim mengatakan bahwa masih banyak pelaku usaha di Kota Pekanbaru yang tidak melaporkan jumlah tenaga kerja lokal yang bekerja, padahal perusahaan wajib melaporkan jumlah tenaga kerjanya setiap bulan kepada Dinas Tenaga Kerja Kota Pekanbaru. ${ }^{19}$

Berdasarkan fakta-fakta ini menjadi penting diteliti dan ditelaah lebih lanjut permasalahan mengenai implementasi kewajiban pelaporan tenaga kerja bagi pelaku

\footnotetext{
${ }^{18}$ A A I N Marhaeni and others, "Kondisi Pasar Kerja Di Provinsi Bali : Implementasi Undang-Undang Wajib Lapor", Jurnal Buletin Studi Ekonomi, Vol. 22, No.2 (2017), hlm.171.

19 Rhttp://riaugreen.com/view/Pekanbaru/44443/Perusahaan-Wajib-Lapor-Jumlah-Karyawan-Tiap-Bulan.html\#.XbUgFDoxXIU, diakses tanggal 2 Oktober 2019.
} 
usaha toko swalayan Indomaret dan Alfamart di Kota Pekanbaru, kemudian mengungkap berbagai hambatan dan upaya pengimplementasian pelaporan tenaga kerja bagi pelaku usaha toko swalayan Indomaret dan Alfamart di Kota Pekanbaru. Penelitian ini penting dilakukan untuk mengidentifikasi hambatan yang dihadapi pelaku usaha toko swalayan yang belum melaksanakan kewajiban pelaporan jumlah tenaga kerja dan menemukan solusi agar pelaku usaha toko swalayan dapat melaksanakan kewajiban pelaporan jumlah tenaga kerja pada setiap semesternya.

\section{METODE PENELITIAN}

Jenis penelitian hukum empiris yang digunakan pada penelitian ini. Bertujuan mencermati efektifnya hukum berlaku didalam masyarakat merupakan tujuan dari suatu penelitian dalam hukum empiris. Kajian yang mengungkapkan apa adanya fakta merupakan penelitian hukum empiris. Penelitian hukum empiris ini akan menentukan berbagai permasalahan bagi pelaku usaha yang tidak melakukan pelaporan tenaga kerja yang telah diserap kepada Dinas Perindustrian dan Perdagangan pada isetiap semester.

Observasi, kuisioner, wawancara, dan kajian pustaka menjadi cara dalam memperoleh data dalam penelitian ini. Dengan menggunakan empat metode teknik dalam pengumpulan data disebabkan terdapat perbedaan responden dalam penelitian ini. Metode analisa data kualitatif adalah metode yang digunakan dalam penelitian ini, yang merupakan suatu cara dalam menganalisis sehingga menghasilkan data deskriptif analitis, sebagaimana yang disampaikan oleh para responden dalam bentuk lisan ataupun tulisan, meneliti dan mempelajari secara utuh perilaku obyek yang diteliti. ${ }^{20}$

Terdapat dua pertimbangan didalam menentuan Kota Pekanbaru menjadi lokasi dalam penelitian ini. Pertama, Kota Pekanbaru telah berkembang menjadi kota metropolitan yang semakin meningkat jumlah toko swalayan dengan brand Indomaret dan Alfamart. Kedua, pelaku usaha toko swalayan dengan brand Indomaret dan Alfamart belum melaksanakan pelaporan tenaga kerja setiap semester kepada Pemerintah Kota Pekanbaru sebagaimana yang telah diperintahkan

20 Soerjono Soekanto, Pengantar Penelitian Hukum, (Jakarta: UI Press, 2008), hlm. 154. 
oleh Peraturan Daerah Nomor 9 Tahun 2014 tentang Pengelolaan Pasar Rakyat, Pusat Perbelanjaan dan Toko Swalayan.

Untuk memperoleh data dalam penelitian ini, maka para responden yang diperlukan informasinya dalam penelitian ini sebagai berikut: Kepala Dinas Tenaga Kerja Kota Pekanbaru, Kepala Dinas Koperasi, Usaha Kecil dan Menengah Kota Pekanbaru, Kepala Dinas Satuan Polisi Pamong Praja Kota Pekanbaru, Ketua Komisi V Dewan Perwakilan Rakyat Daerah Kota Pekanbaru, Ketua Asosiasi Pengusaha Kota Pekanbaru, dan Pelaku Usaha Kota Pekanbaru.

\section{PEMBAHASAN ANALISIS}

\subsection{Kewajiban Pelaporan Tenaga Kerja Bagi Pelaku Usaha Toko Swalayan Indomaret Dan Alfamart Kota Pekanbaru}

Kota Pekanbaru adalah Ibu Kota Provinsi Riau. Luas wilayah kota Pekanbaru adalah sekitar 632,27 km² dengan 12 Kecamatan dan 83 Kelurahan. Dengan total penduduk Kota Pekanbaru sebanyak 1.117.36 jiwa. ${ }^{21}$ Salah satu pusat ekonomi terbesar di Pulau Sumatera adalah Kota Pekanbaru .22 Kota Pekanbaru telah memperlihatkan perkembangannya yang pesat setelah ditetapkan kembali sebagai Kota Investasi Terbaik Tahun 2018 Tingkat Nasional versi Majalah Sindo. Sebanyak empat kali berturut-turut penghargaan yang sama telah diterima Kota Pekanbaru, yakni 2014, 2015, 2016 dan 2017.23

Di Kota Pekanbaru keberadaan toko modern dengan bentuk minimarket sangat meluas di berbagai tempat dan telah pula merambah sampai ke permukiman padat penduduk. ${ }^{24}$ Pertumbuhan pesat toko swalayan dengan brand Indomaret dan Alfamart terlihat hampir di setiap sudut kota Pekanbaru. Dengan meningkatnya jumlah toko swalayan tentu saja sejalan dengan meningkatnya jumlah tenaga kerja yang dipekerjakan. Bidang jasa dan perdagangan dalam kegiatan sehari-hari banyak menggunakan tenaga kerja di bagian counter atau di bagian lain sesuai dengan

\footnotetext{
21 Data BPS Kota Pekanbaru, 2019.

22 https://id.wikipedia.org/wiki/Kota_Pekanbaru, diakses tanggal 2 Oktober 2019.

23 https://www.halloriau.com/read-pekanbaru-101329-2018-04-01-kelima-kalinya-pekanbaru-jadi-kota-tujuaninvestasi-terbaik-di-indonesia.html, diakses 2 tanggal Oktober 2019.

24 Wita Dwika Listihana, Afvan Aquino, Arizal, "Dampak Keberadaan Mini Market Terhadap Modal Kerja Dan Pendapatan Warung Tradisional Di Kecamatan Rumbai Dan Rumbai Pesisir Kota Pekanbaru", Jurnal Ilmiah Ekonomi Dan Bisnis, Vol. 11, No. 1 (2014), hlm. 554.
} 
pembagian dari manajemen perusahaan. ${ }^{25}$ Kualitas pelayanan sangat diperlukan untuk diterapkan dengan baik demi menjamin berlangsungnya kegiatan perusahaan. ${ }^{26}$

Dalam merespon kemajuan kota dan meningkatnya pertumbuhan minimarket, Pemerintah Kota Pekanbaru telah memberlakukan Peraturan Daerah Kota Pekanbaru Nomor 09 Tahun 2014 tentang Pengelolaan Pasar Rakyat, Pusat Perbelanjaan dan Toko Swalayan. Peraturan Daerah ini mengatur berbagai hal mengenai pengelolaan pasar rakyat hingga toko swalayan. Salah satu catatan krusial dalam Peraturan Daerah ini ialah mengenai ketentuan pelaporan tenaga kerja. Pasal 52 ayat (1) poin d menyatakan bahwa pelaku usaha wajib menyampaikan laporan berupa jumlah tenaga kerja yang diserap. Pelaksanaan pelaporan yang dilakukan oleh para pelaku usaha bertujuan agar terhindar sanksi dari pemerintah, persyaratan untuk mempekerjakan tenaga kerja asing dan sebagai indikator kepedulian perusahan terhadap kesejahteraan karyawan. ${ }^{27}$

Pemberlakuan Peraturan Daerah tersebut belum berbanding lurus dengan kesiapan pelaku usaha toko swalayan melaksanakan kewajibannya untuk melaporkan jumlah tenaga kerja kepada pemerintah Kota Pekanbaru. Berdasarkan hasil observasi, pelaku usaha toko swalayan Indomaret dan Alfamart di Kota Pekanbaru belum merespon positif pemberlakuan Peraturan Daerah tersebut. Hal ini bisa dibuktikan dengan banyak pelaku usaha toko swalayan Indomaret dan Alfamart yang belum melaporkan jumlah tenaga kerja setiap semester kepada Dinas Perindustrian dan Perdagangan Kota Pekanbaru.

Selain hasil observasi tersebut, peneliti juga memberikan kuesioner kepada responden para pelaku usaha toko swalayan Alfamart mengenai pelaporan jumlah tenaga kerja. Responden belum mengetahui pemberlakuan Peraturan Daerah Kota Pekanbaru Nomor 9 Tahun 2014 tentang Pengelolaan Pasar Rakyat, Pusat Perbelanjaan Dan toko Swalayan. Namun responden mendukung adanya peraturan

\footnotetext{
25 Cevonie. M Gantung; Prisilia. F Worung, "Perlindungan Hukum Terhadap Tenaga Kerja (Outsourcing) Dalam Kegiatan Perdagangan Jasa Di Kota Manado", Jurnal Lex et Societatis, Vol. 5, No. 10 (2017), hlm. 48.

26 Henni Noviasari, "Pengaruh Retail Service Quality Terhadap Kepuasan Konsumen Berbelanja Di Metro Swalayan Senapelan Plaza Pekanbaru", Jurnal Ekonomi, Vol. 20, No. 3 (2012), hlm 2.

27 Syiti Romallia, "Mengapa Wajib Lapor Tenaga Kerja (WLTK) Wajib Dilakukan Oleh Pemerintah?", https://www.gadjian.com/blog/2018/08/01/mengapa-wajib-lapor-tenaga-kerja-wltk-wajib-dilaklukan-olehperusahaan/ Agustus, 2018, diakses tanggal 2 Mei 2020.
} 
daerah ini dan wajib dilaksanakan agar tenaga kerja yang bekerja di berbagai toko swalayan di Kota Pekanbaru bisa lebih terdata dengan baik. ${ }^{28}$ Responden mengakui belum melaksanakan perintah peraturan daerah tersebut.

Berkenaan kewajiban pelaporan tenaga kerja ini, Kepala Dinas Perindustrian dan Perdagangan Kota Pekanbaru mengatakan bahwa pada prinsipnya pelaporan tenaga kerja bagi para pelaku usaha wajib dilakukan agar pemerintah dapat mengetahui berapa jumlah tenaga kerja yang ada dan bisa dilakukan pengawasan di lapangan. ${ }^{29}$ Namun responden tidak memberikan data mengenai jumlah toko swalayan Indomaret dan Alfamart di Kota Pekanbaru yang telah menyerahkan pelaporan tenaga kerjanya.

Pada kesempatan lain, Ketua Assosiasi Pengusaha Kota Pekanbaru mengemukakan bahwa sepanjang pengetahuannya belum ada informasi mengenai pelaku usaha toko swalayan Indomaret dan Alfamart Kota Pekanbaru yang telah melakukan pelaporan jumlah tenaga kerja yang diserap pada setiap semester kepada Dinas Perindustrian dan Perdagangan. ${ }^{30}$ Dari jawaban responden ini menunjukkan bahwa dinas terkait belum memberikan informasi kepada publik mengenai pelaporan tenaga kerja yang terserap di berbagai took swalayan di Kota Pekanbaru.

Ketua Komisi II DPRD Kota Pekanbaru turut memberikan pendapatnya mengenai kewajiban pelaporan tenaga kerja. Menurut Ketua Komisi II, harus ada pelaporan tenaga kerja terlebih dahulu agar dapat diketahui berapa jumlah daya serap tenaga kerja produktif dan mencegah terjadinya penyimpangan tenaga kerja. Perusahaan harus menyerap tenaga kerja tempatan (tenaga kerja lokal) Kota Pekanbaru sebanyak 70\% dan sisanya menyerap tenaga kerja dari luar Kota Pekanbaru. Ketua Komisi II menegaskan bahwa apabila ada perusahaan yang tidak melakukan pelaporan jumlah tenaga kerjanya, maka perusahaan itu semestinya dikenakan sanksi administrasi. Ketua Komisi II mengemukakan bahwa sebenarnya Pemerrintah Kota Pekanbaru sudah mensosialisasikan ketentuan yang terdapat

\footnotetext{
${ }^{28}$ Wawancara dengan Ibu Lestari, Kepala Toko Swalayan Alfamart, pada tanggal 7 Februari 2020, pukul 10.07 WIB, di Alfamart.

29 Wawancara dengan Bapak Ingot Hutasoit, Kepala Dinas Perindustrian Dan Perdagangan Pemerintah Kota Pekanbaru, tanggal 4 Februari 2020, Pukul 10.00 WIB di Kantor Dinas Perindustrian dan Perdagangan Kota Pekanbaru.

30 Wawancara dengan Bapak Dr. Fahrial ME, Ketua Asosiasi Pengusaha Indonesia Kota Pekanbaru, pada tanggal 6 Februari 2020, Pukul 13.00 WIB, di Universitas Islam Riau.
} 
dalam peraturan daerah ini kepada seluruh pelaku usaha toko swalayan. Hal ini bisa dibuktikan dengan adanya himbauan Pemerrintah Kota Pekanbaru sejak peraturan daerah ini akan diundangkan. ${ }^{31}$

Mencermati hasil wawancara dengan para responden tersebut terlihat jelas bahwa implementasi pelaporan tenaga kerja yang diserap oleh pelaku usaha toko swalayan Indomaret dan Alfamart di Kota Pekanbaru belum terlaksana sebagaimana diatur dalam Peraturan Daerah Kota Pekanbaru Nomor 9 Tahun 2014 tentang Pengelolaan Pasar Rakyat, Pusat Perbelanjaan Dan toko Swalayan.

Terlepas dari beragam pendapat tersebut, peneliti mencermati bahwa perilaku pelaku usaha toko swalayan Indomaret dan Alfamart yang tidak melakukan pelaporan tenaga kerja yang telah diserap menunjukan sikap ketidakpatuhan terhadap Peraturan Daerah Kota Pekanbaru Nomor 9 Tahun 2014 tentang Pengelolaan Pasar Rakyat, Pusat Perbelanjaan Dan toko Swalayan dan sikap yang tidak kooperatif denganpemerintah Kota Pekanbaru. Kenyataan ini tidak boleh terjadi karena pelaku usaha dan pemerintah Kota Pekanbaru seharusnya senantiasa bersinergi mengenai pelaporan jumlah tenaga kerja dan penyerapan tenaga kerja lokal.

\subsection{Kendala Pelaporan Tenaga Kerja Bagi Pelaku Usaha Toko Swalayan Indomaret Dan Alfamart Kota Pekanbaru}

Beragam kendala dalam pengimplementasian kewajiban pelaporan jumlah tenaga kerja oleh pelaku usaha toko swalayan di Kota Pekanbaru. Responden yang merupakan pengelola usaha toko swalayan Alfamart beralasan tidak mengimplementasikan kewajiban pelaporan jumlah tenaga kerja disebabkan tidak mengetahui adanya pemberlakuan Peraturan Daerah Nomor 9 Tahun 2014 tentang Pengelolaan Pasar Rakyat, Pusat Perbelanjaan dan Toko Swalayan. Responden memperkuat alasannya dengan mengatakan bahwa Pemerintah Kota pekanbaru

\footnotetext{
31 Wawancara dengan Bapak Fathullah, S.Sos, Ketua Komisi II DPRD Kota Pekanbaru, tanggal 18 Februari 2020, pukul 14.02 WIB, di Gedung DPRD Kota Pekanbaru.
} 
belum pernah melakukan sosialisasi mengenai peraturan daerah tersebut kepada masyarakat, termasuk pelaku usaha toko swalayan di Kota Pekanbaru. ${ }^{32}$

Hampir senada dengan alasan pelaku usaha tersebut, Ketua Assosiasi Pengusaha Kota Pekanbaru mengatakan bahwa kendala belum diimplementasikannya kewajiban pelaporan jumlah tenaga kerja oleh pelaku usaha toko swalayan disebabkan belum mendapatkan informasi terkait peraturan daerah tersebut, sehingga mengakibatkan belum tumbuh kesadaran pelaku usaha toko swalayan Indomaret dan Alfamart untuk melakukan pelaporan tenaga kerja. ${ }^{33}$

Dari pendapat responden tersebut memperlihatkan bahwa hanya pelaku usaha toko swalayan dan Ketua Assosiasi Pengusaha Kota Pekanbaru yang memberikan komentar mengenai pelaporan tenaga kerja, sedangkan responden yang lainnya tidak memberikan komentar yang pasti mengenai pelaporan tenaga kerja. Dari beberapa pendapat yang disampaikan menunjukkan bahwa masih sangat kurang komitmen Dinas Perindustrian dan Perdagangan Kota Pekanbaru untuk melaksanakan perintah Pasal 52 ayat (1) poin d Peraturan Daerah Nomor 9 Tahun 2014 tentang Pengelolaan Pasar Rakyat, Pusat Perbelanjaan dan Toko Swalayan.

Ketidakpatuhan pelaku usaha toko swalayan Indomaret dan Alfamart disebabkan tidak diterapkannya sanksi yang berlaku terhadap pelaku usaha toko swalayan Indomaret dan Alfamart yang tidak melakukan pelaporan jumlah tenaga kerja yang diserap pada setiap semester. Kendala tidak diterapkannya sanksi terhadap pelaku usaha toko swalayan disebabkan tidak adanya pengawasan dari instansi terkait mengenai pemberlakuan peraturan daerah tersebut.

Sesungguhnya penting adanya pengawasan terhadap pemberlakuan peraturan daerah tersebut. Sebab, fungsi pengawasan bertujuan terciptanya penyelenggaraan pengawasan yang bersinergi antara pengawasan ketenagakerjaan di tingkat pusat dan daerah agar efektif dan optimal, menjadikan fungsi pengawasan dan penegakan hukum ketenagakerjaan lebih independen, terpadu, terkoordinasi dan terintegrasi. ${ }^{34}$ Apabila sisitem pengawasan tidak berjalan dengan baik, maka pelaksanaan suatu

\footnotetext{
32 Wawancara dengan Ibu Lestari, Kepala Toko Alfamart, pada tanggal 7 Februari 2020, pukul 10.07 WIB, di Alfamart.

33 Wawancara dengan Bapak Dr. Fahrial ME, Ketua Aosiasi Pengusaha Indonesia Kota Pekanbaru, pada tanggal 6 Februari 2020, Pukul 13.00 WIB, di Universitas Islam Riau.

${ }^{34} \mathrm{Ni}$ Wayan Winiarti, "Pelaksanaan Wajib Lapor Ketenagakerjaan Setelah Berlakunya Undang-Undang Nomor 23 Tahun 2014", Jurnal Acta Comitas, Vol. 4, No. 1 (2019), hlm.137.
} 
peraturan tidak akan bisa maksimal. Oleh karena itu, laporan ketenagakerjaan yang disampaikan oleh para pelaku usaha adalah bahan informasi yang resmi bagi pemerintah untuk menetapkan kebijaksanaan bidang ketenagakerjaan, diantaranya meliputi perlindungan tenaga kerja, pembinaan hubungan industrial diperusahaan, dan peningkatan perluasan kesempatan kerja. ${ }^{35}$

\subsection{Upaya Pelaporan Tenaga Kerja Bagi Pelaku Usaha Toko Swalayan Indomaret Dan Alfamart Kota Pekanbaru}

Beragam pendapat mengenai upaya pelaporan tenaga kerja bagi pelaku usaha toko swalayan Indomaret dan Alfamart di Kota Pekanbaru. Responden yang merupakan pengelola usaha toko swalayan Alfamart mengatakan bahwa sebaiknya Pemerintah Kota Pekanbaru turun langsung ke lapangan mengunjungi toko swalayan Indomaret dan Alfamart sebulan sekali untuk dapat mengetahui secara nyata bagaimana keadaan sesungguhnya dan secara terus menerus melakukan sosialisasi peraturan daerah tersebut kepada pelaku usaha toko swalayan. ${ }^{36}$ Upaya seperti ini penting dilakukan dinas terkait agar pelaku usaha toko swalayan menyadari kewajiban untuk melakukan pelaporan jumlah tenaga kerjanya. Oleh sebab itu, sangat diperlukan perhatian dan respon yang cepat dari Dinas Perindustrian dan Perdagangan Pemerintah Kota Pekanbaru untuk menindaklanjuti beberapa upaya tersebut agar pelaku usaha melaksanakan kewajibannya menyampaikan pelaporan jumlah tenaga kerjanya pada setiap semesternya.

Dalang rangka pemberlakuan peraturan daerah tersebut, Kabid Penegakan Peraturan Daerah Satuan Polisi Pamong Praja Pemerintah Kota Pekanbaru berpendapat bahwa Dinas Tenaga Kerja Pemerintah Kota Pekanbaru perlu melakukan pembinaan dan pengawasan terhadap pelaku usaha yang memanfaatkan tenaga kerja. Selain itu, perlu adanya koordinasi antara dinas Perindustrian dan Perdagangan dan Dinas Tenaga Kerja Kota Pekanbaru, Dinas Tenaga Kerja Pemerintah Kota Pekanbaru, dan Satuan Polisi Pamong Praja Pemerintah Kota

\footnotetext{
35 Ibid, hlm 139.

36 Wawancara dengan Ibu Lestari, Kepala Toko Alfamart, pada tanggal 7 Februari 2020, pukul 10.07 WIB, di Alfamart.
} 
Pekanbaru untuk memastikan terlaksananya kewajiban pelaku usaha untuk melakukan pelaporan tenaga kerjanya pada setiap semesternya.$^{37}$

Ketua Asosiasi Pengusaha Indonesia Kota Pekanbaru memberikan pendapat mengenai upaya kewajiban pelaporan tenaga kerja ini. Pertama, Pemerintah Kota Pekanbaru perlu mensosialisasikan terus menerus Peraturan Daerah Nomor 9 Tahun 2014 tentang Pengelolan Pasar Rakyat, Pusat Perbelanjaan dan Toko Swalayan ini. Kedua, Pada tahun 2020, setiap pelaku usaha yang menjadi anggota Asosiasi Pengusaha Indonesia Kota Pekanbaru saling berkoordinasi untuk mematuhi Surat Edaran Gubernur Provinsi Riau agar dapat melaksanakan Peraturan Daerah Nomor 9 Tahun 2014. Ketiga, Pemerintah Kota Pekanbaru bekerjasama dengan Asosiasi Pengusaha Indonesia Kota Pekanbaru monitoring realiasi pelaksaaan kewajiban pelaku usaha toko swalayan Indomaret dan Alfamart. Keempat, apabila Pemerintah Kota Pekanbaru telah melakukan sosialisasi terhadap peraturan daerah tersebut, maka Pemerintah Kota Pekanbaru harus konsisten menerapkan sanksi terhadap pelaku usaha toko swalayan yang tidak menjalankan kewajibannya sesuai dengan aturan yang berlaku. ${ }^{38}$

Ketua Komisi II DPRD Kota Pekanbaru melengkapi pendapat Ketua Asosiasi Pengusaha Indonesia Kota Pekanbaru tersebut. Ketua Komisi II memberikan dua pendapatnya mengenai upaya kewajiban pelaporan tenaga kerja ini, Pertama, Pemerintah Kota Pekanbaru perlu mengingatkan pelaku usaha toko swalayan Indomaret dan Alfamart mengenai kewajibannya untuk melakukan pelaporan jumlah tenaga kerja secara rutin. Kedua, Dinas terkait perlu menyampaikan informasi melalui surat kepada pelaku usaha mengenai batas waktu pengajuan laporan jumlah tenaga kerja pada setiap semester. ${ }^{39}$

\footnotetext{
37 Wawancara dengan Bapak Rudy Afrianda, S.H, Kepala Bidang Penegakan Peraturan Daerah Satuan Polisi Pamong Praja Kota Pekanbaru, pada tanggal 4 Februari 2020, pukul 14.12 WIB, di Kantor Dinas Satuan Polisi Pamong Praja Pemerintah Kota Pekanbaru.

38 Wawancara dengan Bapak Dr. Fahrial ME, Ketua Asosiasi Pengusaha Indonesia Kota Pekanbaru, pada tanggal 6 Februari 2020, Pukul 13.00 WIB, di Universitas Islam Riau.

${ }^{39}$ Wawancara dengan Bapak Fathullah, S.Sos, Ketua Komisi II DPRD Kota Pekanbaru, tanggal 18 Februari 2020, pukul 14.02 WIB, di Gedung DPRD Kota Pekanbaru.
} 


\section{PENUTUP}

\subsection{Kesimpulan}

Hasil penelitian ini dapat disimpulkan bahwasanya para pelaku usaha toko swalayan belum mengetahui ketentuan yang terdapat dalam peraturan daerah tersebut, namun siap untuk melaksanakan kewajiban pelaporan tenaga kerja. Pemerintah Kota Pekanbaru menyadari belum melaksanakan perintah peraturan daerah agar pelaku usaha memberikan pelaporan tenaga kerja. Ketua Assosiasi Pengusaha Kota Pekanbaru belum mendapat informasi mengenai pelaku usaha yang telah melaksanakan kewajiban pelaporan jumlah tenaga kerja. Sementara Ketua Komisi II DPRD Kota Pekanbaru telah rmenyampaikan kepada pemerintah mengenai adanya kewajiban pelaku usaha untuk memberikan pelaporan jumlah tenaga kerjanya.

Kendala pengimplementasian kewajiban pelaporan jumlah tenaga kerja disebabkan pelaku usaha belum memperoleh informasi mengenai peraturan daerah mengenai pelaporan jumlah tenaga kerjanya, Pemerintah Kota Pekanbaru kurang kuat komitmennya untuk melaksanakan peraturan daerah tersebut dan belum menerapkan sanksi terhadap pelaku usaha yang tidak melakukan pelaporan jumlah tenaga kerja, Ketua Asosiasi Pengusaha Kota Pekanbaru belum mendapatkan informasi adanya pemberlakuan peraturan daerah mengenai pelaporan jumlah tenaga kerjanya. Selain itu, tidak adanya pengawasan terhadap dinas terkait yang bertugas untuk melaksanakan peraturan daerah mengenai kewajiban pelaku usaha melakukan pelaporan jumlah tenaga kerjanya.

Upaya pengimplementasian kewajiban pelaporan jumlah tenaga kerja, antara lain: Pemerintah Kota Pekanbaru harus mengunjungi toko swalayan sebulan sekali untuk dapat mengetahui keadaan sesungguhnya dan melakukan sosialisasi peraturan daerah tersebut kepada pelaku usaha toko swalayan, Dinas terkait perlu menyampaikan informasi melalui surat kepada pelaku usaha mengenai batas waktu pengajuan laporan jumlah tenaga kerja pada setiap semester, Dinas Tenaga Kerja perlu melakukan pembinaan dan pengawasan terhadap pelaku usaha yang memanfaatkan tenaga kerjanya, Dinas terkait perlu melakukan koordinasi untuk memastikan terlaksananya kewajiban pelaku usaha pelaporan tenaga kerjanya, 
Asosiasi Pengusaha Indonesia harus mendorong anggotanya agar mematuhi Surat Edaran Gubernur Provinsi Riau, Pemerintah dan Asosiasi Pengusaha Indonesia perlu bekerjasama memonitoring pelaksaaan kewajiban pelaku usaha toko swalayan, dan Pemerintah harus konsisten menerapkan sanksi terhadap pelaku usaha toko swalayan yang tidak menjalankan kewajibannya sesuai dengan aturan yang berlaku.

\subsection{Saran}

Dinas Tenaga Kerja dan Dinas Perindustrian Pemerintah Kota Pekanbaru perlu menyatukan presepsi dan bersama-sama mendorong pelaku usaha toko swalayan untuk melaksanakan kewajiban pelaporan jumlah tenaga kerjanya. Di samping itu, Pemerintah Kota Pekanbaru harus secara rutin mengingatkan dan mengirim surat kepada pelaku usaha toko swalayan mengenai batas waktu pengajuan laporan jumlah tenaga kerja pada setiap semester.

\section{DAFTAR PUSTAKA}

Abidin, Zainal, 'Pelaksanaan Peraturan Daerah Nomor 09 Tahun 2014 Tentang Pengelolaan Pasar Rakyat, Pusat Perbelanjaan Dan Toko Swalayan (Indomaret Dan Alfamart Kota Pekanbaru) 1.2', Http://Repository.UinSuska.Ac.Id/14788/6/6.\%20BAB\%20I_2018817ADN.Pdf (uin suska, 2018)

Data BPS Kota Pekanbaru, 2019.

Fathoni, JHamdiyah;Andi Triharyono;Azis, 'Peningkatan Kinerja Karyawan Melalui Kompetensi Lingkungan Kerja Dan Gaya Kepemimpinan Di Ada Swalayan Banyumanik Semarang', Of Management, 02.02 (2016).

Mahyuni, Lina Wana, 'Implementasi Peraturan Daerah Nomor 09 Tahun 2014 Tentang Pengelolaan Pasar Rakyat, Pusat Perbelanjaan Dan Toko Swalayan (Pengawasan Pusat Perbelanjaan Dan Toko Swalayan Tidak Berizin) Kelurahan Simpang Baru Kota Pekanbaru.', Http://Repository.UinSuska.Ac.Id/14780/6/6.\%20BAB\%20I_2018815ADN.Pdf (uin suska, 2018).

Marhaeni, A A I N, I G W Murjana Yasa, Ni Nyoman Yuliarmi, Ni Putu, Martini Dewi, and Ketenagakerjaan Perusahaan, 'Kondisi Pasar Kerja Di Provinsi Bali: Implementasi Undang-Undang Wajib Lapor', Buletin Studi Ekonomi, 22.2 (2017), 171.

Noviasari, Henni; Azrico, 'Pengaruh Retail Service Quality Terhadap Kepuasan Konsumen Berbelanja Di Metro Swalayan Senapelan Plaza Pekanbaru', Ekonomi, 20.3 
Nur, Trisdiana M., 'Analisis Perubahan Pendapatan Usaha Pedagang Eceran Sebelum Dan Sesudah Berdirinya Indomaret Dan Alfamart Di Kecamatan Tampan Pekanbaru', JOM FEKON, 2.2 (2015).

Otaviana, Trivita;M.Mahdil Mawahib;Abdullah Taufik, 'Analisis Strategi Penjualan Barang Komoditas Di Swalayan Surya Gondang Prespektif Hukum Ekonomi Syariah', Qawanin, 3.2 (2019).

Puspita, Rizki Nuri, 'Perbedaan Kepuasan Pelanggan Indomaret Dan Alfamart', of Social And Industrial Psychologi, 1.1 (2012).

Putri, Vini Anggraini, and Dewi Fatmasari, 'Hubungan Kualitas Pelayanan Dengan Kepuasan Pelanggan Alfamart Di Kelurahan Srondol Wetan Semarang', Majalah Ilmiah Inspiratif, 3.5 (2018).

Ramadhani, Jun, 'Kebijakan Pemberian Izin Usaha Toko Modern Alfamart Dan Indomaret Oleh Pemerintah Kota Pekanbaru Berdasarkan Peraturan Presiden Nomor 112 Tahun 2007 Tentang Penataan Dan Pembinaan Pasar Tradisional Pusat Perbelanjaan Dan Toko Modern', JOM Fakultas Hukum, 2.1 (2015).

Ria, Lisa Tina, 'Analisis Faktor - Faktor Yang Mempengaruhi Prilaku Konsumen Berbelanja Pada Swalayan 999 Pekanbaru' (Uin Suska, 2012).

Riau.com, Hallo, 'Kelima Kalinya, Pekanbaru Jadi Kota Tujuan Investasi Terbaik Di Indonesia', HalloRiau, 2020.

RiauGreen.com, 'Perusahaan Wajib Lapor Jumlah Karyawan Tiap Bulan', RiauGreen.Com, 2019.

Riyadi, Dicky Taufik, 'Pengawasan Dinas Perindustrian Dan Perdagangan Terhadap Izin Usaha Toko Modern (IUTM) Di Kota Pekanbaru', JOM FISIP, 4.9 (2017).

Romallia, Syiti, 'Mengapa Wajib Lapor Tenaga Kerja (WLTK) Wajib Dilakukan Oleh Pemerintah ?', Agustus, 2018.

Saib, Khaidir, 'Strategi Kesuksesan Pertumbuhan Pasar Swalayan Studi Kasus : Toko Mini Market Di Kota Pekanbaru', Equibrium, 7.2 (2019).

Soekanto, Soerjono, Pengantar Penelitian Hukum (UII Pres, 2008).

Sukmawati, Mia Ayu, 'Pengawasan Izin Usaha Toko Modern (IUTM) Oleh Dinas Perdagangan Dan Perindustrian Kota Pekanbaru (Studi Kasus Ritel Alfamart Dan Indomaret)', JOM FISIP, 5.II (2018).

Widiawati, Ikeu Kania; Windy, 'Pengaruh Pembagian Kerja Terhadap Kinerja Pegawai Di UPTD Pasar Cisurupan Dinas Perindustrian Dan Perdagangan Kecamatan Cisurupan Kabupaten Garut', Pembangaunan Dan Kebijakan Publik, 10.2 (2019).

Winiarti, Ni Wayan, 'Pelaksanaan Wajib Lapor Ketenagakerjaan Setelah Berlakunya Undang-Undang Nomor 23 Tahun 2014', Acta Comitas, 4.1 (2019).

Wita Dwika Listihana, Afvan Aquino, Arizal, 'Dampak Keberadaan Mini Market Terhadap Modal Kerja Dan Pendapatan Warung Tradisional Di Kecamatan Rumbai Dan Rumbai Pesisir Kota Pekanbaru', Ilmiah Ekonomi Dan Bisnis, 11.1 (2014). 
Worung, Cevonie. M Gantung;Prisilia. F, 'Perlindungan Hukum Terhadap Tenaga Kerja (Outsourcing) Dalam Kegiatan Perdagangan Jasa Di Kota Manado', Lex et Societatis, V.10 (2017).

Yasin, Muhammad; Sri lestari, Ekonomi (Ganeca Exact, 2007).

Yola, Melfa, and Duwi Budianto, 'Analisis Kepuasan Konsumen Terhadap Kualitas Pelayanan Dan Harga Produk Pada Supermarket Dengan Menggunakan Metode Importance Performance Analysis (IPA)', Jurnal Optimasi Sistem Industri, 12.1 (2016). 